\title{
Firm Performance Following Auditor Changes For Audit Fee Savings
}

\author{
Kam C. Chan, Pace University, USA \\ Barbara Farrell, Pace University, USA \\ Patricia Healy, Pace University, USA \\ Picheng Lee, Pace University, USA
}

\begin{abstract}
This study examines stock and earnings performance subsequent to auditor changes by firms specifically for audit fees savings without any other apparent regulatory or disclosure issues. Results show that there is mild evidence of positive stock return and earnings performance after changing auditors. There is also no significant difference in company performance among different types of auditor changes when looking at auditor changes among and between Big 4 and non-Big 4 auditors. Finally, we find that the positive firm performance is mainly among auditor changes made before 2003.
\end{abstract}

Keywords: Auditor Change; Audit Fee Savings; Firm Performance

\section{INTRODUCTION}

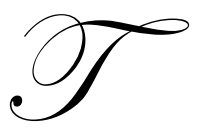

here have been an increasing number of companies changing auditors in recent years. For example, Grothe and Weirich (2007) find that 1,322 firms have changed their auditors in 2006, representing $10.4 \%$ of public firms. A key trend among the auditor changes is the switch from Big 4 auditors to non-Big 4 auditors (Owens-Jackson, Robinson, and Shelton 2006; Hogan and Martin 2009). One reason for these auditor changes is for firms to have audit fee savings in terms of audit fees reduction or a lower rate of audit fee increase with the new auditor. An excerpt from an $8-\mathrm{K}$ report is presented below:

On September 26, 2006, Zix Corporation (the "Company") engaged Whitley Penn LLP ("Whitley Penn") as its independent registered public accounting firm to audit the Company's financial statements for the year ended December 31, 2006. On September 26, 2006, the Company also notified Deloitte \& Touche LLP ("D\&T"), its independent registered public accounting firm for the year ended December 31, 2004, and December 31, 2005, of its election to dismiss D\&T as the Company's independent registered public accounting firm. The foregoing was undertaken as a cost reduction effort by the Company and has been approved by the Audit Committee of the Company's Board of Directors.

Although there could be audit fee savings in the use of non-Big 4 auditors, the quality of audit could be lower. Auditors are considered as external monitors to reduce agency costs by verifying the reliability of financial reports (Jensen and Meckling 1976). Findings in the literature generally suggest that the services performed by Big $4 / 6 / 8$ auditors are of better quality than non-Big 4/6/8 auditors in monitoring firms' reporting activities. For example, Becker et al. (1998) and Francis et al. (1999) find that firms with Big 6 auditors have less earnings management in term of lower discretionary accruals. Prior studies have also examined the effects of auditor changes on firms. Teoh and Wong (1993) show that firms switching from Big 8 auditors to non-Big 8 auditors have lower investor responses to their announced earnings after the changes. Hackenbrack and Hogan (2002) extend the analysis of Teoh and Wong and show that the decrease in investor responses to earnings announcements is partly caused by auditor changes due to fee-reductions. Overall, the findings suggest that investors consider earnings information to be less credible after the firms have switched to smaller auditors. 
The research objective of this study is to examine the long-term stock and earnings performance of firms changing auditors for audit fee savings. Firms often change auditors for negative reasons such as having disagreements with auditors and receiving going-concern or ineffective internal control opinions. This study focuses on firms with auditor changes specifically for a reduction in audit fees. Audit fee savings can provide direct economic benefits to shareholders in the form of lower operating expenses. However, there are possible negative effects of auditor changes for audit fee savings. First, non-Big 4 auditors or auditors with less compensation could be less effective in monitoring firms' activities. Therefore managers in those situations are more likely to engage in activities that are not in the best interests of shareholders. Thus, agency costs could be higher and firm value would be lower. Second, the change to non-Big 4 auditors or auditors with less compensation could be a negative signal on the future prospects of firms. Since larger auditors can provide more compensation to outsider shareholders in audit failure, Bar-Yosef and Livnat (1984) develop a signaling model, which suggest that firms switched to larger auditors in order to signal expectation of higher future cash flows. Johnson and Lys (1990) also suggest that firms with more growth opportunities are more likely to have complex operations and accounting policies. Thus, the larger auditors are needed for these firms to support their future growth. The switch to non-Big 4 auditors or less compensated auditors could be negative signals that there are limiting future growth opportunities.

Specifically, we examined the stock and earnings performance of firms following their auditor change to reduce audit fees. The findings should be of interest to investors in accessing the net economic effect of auditor changes for audit fee savings. The remainder of this study is organized as follows. Section 2 provides a summary of related literature and research objective. The research design is described in Section 3. Section 4 presents the research findings and Section 5 provides some concluding remarks.

\section{RELATED LITERATURE AND RESEARCH OBJECTIVE}

Grothe and Weirich (2007) provide some interesting statistics on the increasing number of auditor changes in recent years. For example, in the 4-year period ending in 2006, about 59\% of public companies have changed auditors. Small firms with less than $\$ 75$ million in market capitalization represent $79 \%$ of the firms with auditor changes in this period. Both Grothe and Weirich (2007) and Turner et al. (2005) found that the majority of firms did not provide any reasons for the auditor changes. One of the key trends in recent years is the shift from Big 4 accounting firms to second-tier or smaller accounting firms. Audit fee savings is often cited as a key reason for the changes, especially in minimizing the compliance costs of Sarbanes-Oxley Act of 2002 (SOX). Ettredge et al. (2007) found that immediately after the passage of SOX, firms paying higher audit fees are more likely to switch auditors to reduce audit costs. They also find that smaller firms are more likely to switch to non-Big 4 auditors to realize the cost savings.

Recent students have examined the effects on firms that changed their auditors from Big 4 accounting firms to non-Big 4 accounting firms. It is generally believed that the work performed by Big 4 auditors is of higher quality than that of non-Big 4 auditors. Thus, the switch to non-Big 4 auditors by firms could have negative effects on firms. Chang et al. (2010) examines the market reactions to announcements by firms in switching from Big 4 auditors to non-Big 4 auditors in 2002-2006. They find that the market reaction is nonnegative, suggesting that investors do not perceive the change to non-Big 4 auditors as negative news. Krishnan et al. (2008) looked at firms changing from Big 4 auditors to non-Big 4 auditors to determine if they have more earnings management. The authors did not find significantly greater amount of earnings management among firms that changed their auditors from Big 4 accounting firms to non-Big 4 accounting firms. The insignificant effect occurred mainly after the passage of SOX, whereas the authors did find evidence of greater earnings management in the pre-SOX period. These findings are consistent with that of Hackenbrack and Hogan (2002) - firms that changed auditors for audit fee savings have lower earnings quality in the pre-SOX period.

The objective of this study is to examine the long-term stock and earnings performance of firms changing auditors specifically for audit fee savings. Firms often change auditors for multiple and/or negative reasons such as having going concern or ineffective internal control opinions. In this study, we examine a sample of firms that change auditor specifically only for audit fee savings without other cited major or apparent negative reasons. The sampling procedures are discussed in the next section. Changes in auditors could be associated with negative implications. Non-Big 4 auditors or auditors with less compensation could be less effective in monitoring 
management activities. This could, in turn, allow management to engage in activities that do not maximize firm value. Changes in auditors for audit fee savings could also be associated with negative signals about future prospects of firms. Prior studies find that firms with more growth opportunities and financing activities are more likely to have Big 4/6/8 auditors, in order to reduce their cost of capital since investors perceive that these auditors are of high quality in reducing agency cost (Mansi et al. 2004; Cahan et al. 2008; Venkataraman et al. 2008; and Chang et al. 2009). These empirical findings are consistent with the predictions from Bar-Yosef and Livnat (1984) and Johnson and Lys (1990) finding that firms expecting substantial future growth are likely to have Big 4 auditors. Thus, changing auditors for audit fee savings may suggest poor or limited future prospects for firms as less auditing services are needed, particularly if the firms changed auditors from Big 4 accounting firms to non-Big 4 accounting firms. The objective of this study is to examine the stock and earnings performance of firms after their auditor changes for audit fee savings.

\section{RESEARCH DESIGN}

An initial sample of firms changing auditors was downloaded from the Audit Analytics database. Audit Analytics provides reasons for the auditor changes. To be included in the final sample, a firm must:

(1) indicate that audit fee reduction is a reason for the auditor change;

(2) not have any reportable events such as disagreement with auditor, restatement, or other negative reporting issues;

(3) not have a going concern opinion;

(4) not have material internal or disclosure control weaknesses;

(5) not be a subsidiary or have the auditor change for its subsidiary or pension benefit plan only;

(6) initiate the auditor dismissal;

(7) not have Arthur Andersen as the dismissed author;

(8) not be a foreign company; and

(9) have the auditor change announced by the end of 2006.

The sample consists of firms that changed auditors for audit fee savings without other apparent disclosure problems. The auditor changes are also not forced changes because of regulatory problems of the dismissed auditors. To be included in the final sample, the firm must have sufficient stock and financial statement data as discussed below. Stock performance of the sample firms after their auditor changes are analyzed using the 4-factor model with pricing factors suggested by Fama and French (1993) and Carhart (1997).

$\mathrm{R}_{\mathrm{it}}-\mathrm{R}_{\mathrm{ft}}=\alpha+\mathrm{b}\left(\mathrm{R}_{\mathrm{mt}}-\mathrm{R}_{\mathrm{ft}}\right)+\mathrm{sSMB}_{\mathrm{t}}+\mathrm{hHML} \mathrm{L}_{\mathrm{t}}+\mathrm{uUMD} \mathrm{D}_{\mathrm{t}}+\varepsilon_{\mathrm{t}}$

where

$\mathrm{R}_{\mathrm{it}} \quad=$ daily stock return of firm $\mathrm{i}$ on day $\mathrm{t}$;

$\mathrm{R}_{\mathrm{ft}} \quad=$ daily return of one month Treasury Bill on day $\mathrm{t}$;

$\mathrm{R}_{\mathrm{mt}} \quad=$ daily return of CRSP value-weighted index on day $\mathrm{t}$;

$\mathrm{SMB}_{\mathrm{t}} \quad=$ daily return of the small-minus-big size portfolio on day $\mathrm{t}$;

$\mathrm{HML}_{\mathrm{t}}=$ daily return of the high-minus-low book-to-market portfolio on day $\mathrm{t}$; and

$\mathrm{UMD}_{\mathrm{t}}=$ daily return of the high-minus-low momentum portfolio on day $\mathrm{t}$.

Stock returns are collected from CRSP. The Fama-French and momentum factors are collected from the Wharton Research Data Services. This model is estimated for each of the sample firms using 500 daily returns since the engagement date of the new auditor. The intercept $(\alpha)$ measures the abnormal returns of each firm in this 500day period. We examine if the average $\alpha$ among the sample firms is statistically positive or negative. An average positive (negative) $\alpha$ suggests that the sample firms over-(under-)performed in the stock market after adjusted for their risk factors.

There are four possible cases of the auditor changes. Firms previously with Big 4 auditors could switch to either another Big 4 auditor or non-Big 4 auditors. Firms previously with non-Big 4 auditors could switch to either 
Big 4 auditors or another non-Big 4 auditor. We conducted analysis on the effects of the type of auditor change on stock performance. The following regression is estimated for the sample firms.

$\alpha_{i}=a_{0}+a_{1} B B_{i}+a_{2} B N_{i}+a_{3} N N_{i}+e_{i}$

where

BB $=1$ if firm $\mathrm{i}$ changed auditor from Big 4 auditor to another Big 4 auditor; 0 otherwise;

$\mathrm{BN} \quad=1$ if firm $\mathrm{i}$ changed auditor from Big 4 auditor to a non-Big 4 auditor; 0 otherwise; and

$\mathrm{NN} \quad=1$ if firm $\mathrm{i}$ changed auditor from non-Big 4 auditor to another non-Big 4 auditor; 0 otherwise;

The dependent variable is $\alpha$ from equation (1) above. Since there are very few cases that firms with nonBig 4 auditors change to Big-4 auditors to save audit fees, we have indicator variables for the other three more likely cases. A positive (negative) slope coefficient for $\mathrm{BB}, \mathrm{BN}$, and $\mathrm{NN}$ would suggest there is positive (negative) subsequent stock performance of the sample firms in those groups.

We also examined the change in return on assets in the two fiscal years ending after the change in auditor. Return on assets is defined as income before discontinued operations and extraordinary items divided by average total assets. ROA is computed for each of the two fiscal years ended before the change in auditor and for each of the two fiscal years ended after the change in auditor. Change in ROA is the ROA in the fiscal years ended after the auditor changes minus the average ROA in the two years ended before the auditor changes. Earnings and total assets are collected from Compustat and Mergent Online. Results of the analysis are presented in the following section.

\section{EMPIRICAL FINDINGS}

The final sample consists of 51 firms. Table 1 provides the sample distributions by industry, year, and type of auditor change. About half of the sample firms are manufacturing firms. 16 firms changed auditors in 2004. Raghunandan and Rama (2006) and Eldridge and Kealey (2005) reported an increase in audit fees among accelerated filers of between 86-100\% in 2004. Benoit (2006) also reported a 36\% increase of audit fees among nonaccelerated filers that are not required to comply with Section 404 in 2004. The increase in audit fees among nonaccelerated filers reflects the stricter regulatory environment in the post-SOX period for all firms. The high proportion of sample firms in 2004 is probably due to firms changing auditor to reduce the increase in audit fees. The average total assets of the sample firms is only $\$ 65$ millions which is consistent with the findings in Grothe and Weirich (2007) and Turner et al. (2005) who concluded that most of the auditor changes were made by smaller firms. However, six of the sample firms have total assets of about $\$ 1$ billion or more. As expected from prior studies, 27 of the firms changed their auditors from Big 4 accounting firms to non-Big 4 accounting firms in order to reduce audit fees. There in only one sample firm that changed its auditor from a non-Big 4 accounting firm to a Big 4 accounting firm. There are 9 firms that changed auditors among Big 4 accounting firms and 14 firms that changed auditors to non-Big 4 firms.

Table 2 summarizes the results of the stock return analysis. The mean and median intercept of the 4 -factor model for the sample firms are almost all positive. Not all of the firms have 500 daily returns available after the auditor changes. We have provided analysis for all of the sample firms as a group based on the available data as well as for firms with all 500 daily returns, at least 250 daily returns, or less than 250 daily returns. The mean intercept is positive and statistically significant at the $10 \%$ level for firms with all 500 daily returns. The median intercept is positive and significant at $1 \%$ or $5 \%$ level in three of the four groups. Overall, there is mild evidence that firms have positive risk-adjusted stock return performance after the auditor changes. 
Table 1

Sample Distributions

Panel A: sample distribution by industry

Industries

Number of firms

Construction

2

Manufacturing

25

Transportation, communication, electric, gas and sanitary services

Retail trade

Finance, insurance, and real estate

3

Services

Total

$\frac{11}{51}$

Panel B: sample distribution by year

Years

2000

2001

2002

2003

2004

2005

2006

Total

51

Panel C: sample distribution by type of auditor change

Types of auditor change

Big 4 auditor to Big 4 auditor

Big 4 auditor to non-Big 4 auditor

Non-Big 4 auditor to Big 4 auditor

Non-Big 4 auditor to non-Big 4 auditor

Total

Number of firms

3
9
4
6
16
9
4
51

Number of firms

9
27
1
14
51

Table 2

Analysis of Stock Returns Following Auditor Changes

\begin{tabular}{|c|c|c|c|}
\hline & \multirow[b]{2}{*}{ \# of firms } & \multicolumn{2}{|c|}{ Intercept of 4-factor model $^{\mathrm{a}}$} \\
\hline & & Mean & Median $^{c}$ \\
\hline All firm & 51 & $\begin{array}{c}0.00073 \\
(0.1968)\end{array}$ & $\begin{array}{c}0.00039 \\
(0.0241)\end{array}$ \\
\hline Firms with all 500 daily returns & 38 & $\begin{array}{c}0.00053 \\
(0.0803)\end{array}$ & $\begin{array}{r}0.00047 \\
(0.0336)\end{array}$ \\
\hline Firms with at least 250 daily returns & 45 & $\begin{array}{c}0.00050 \\
(0.1109)\end{array}$ & $\begin{array}{c}0.00063 \\
(0.0066)\end{array}$ \\
\hline Firms with least than 250 daily returns & 6 & $\begin{array}{c}0.00245 \\
(0.6048)\end{array}$ & $\begin{array}{l}-0.00045 \\
(0.6875)\end{array}$ \\
\hline
\end{tabular}

a: $\mathrm{R}_{\mathrm{it}}-\mathrm{R}_{\mathrm{ft}}=\alpha+\mathrm{b}\left(\mathrm{R}_{\mathrm{mt}}-\mathrm{R}_{\mathrm{ft}}\right)+\mathrm{sSMB}_{\mathrm{t}}+\mathrm{hHML}_{\mathrm{t}}+\mathrm{uUMD} \mathrm{UM}_{\mathrm{t}}+\varepsilon_{\mathrm{t}}$

where

$\mathrm{R}_{\mathrm{it}} \quad=$ daily stock return of firm $\mathrm{i}$ on day $\mathrm{t}$;

$\mathrm{R}_{\mathrm{ft}} \quad$ = daily return of one month Treasury Bill on day $\mathrm{t}$;

$\mathrm{R}_{\mathrm{mt}} \quad=$ daily return of CRSP value-weighted index on day $\mathrm{t}$;

$\mathrm{SMB}_{\mathrm{t}} \quad=$ daily return of the small-minus-big size portfolio on day $\mathrm{t}$;

$\mathrm{HML}_{\mathrm{t}}=$ daily return of the high-minus-low book-to-market portfolio on day $\mathrm{t}$; and

$\mathrm{UMD}_{\mathrm{t}}=$ daily return of the high-minus-low momentum portfolio on day $\mathrm{t}$.

b: two-tailed $p$-value for $t$-test of sample mean in parenthesis.

c: two-tailed $p$-value for sign test of sample median in parenthesis.

Table 3 provides the results of the return on assets analysis. The mean and median changes in ROA in the 2-year period, first year, and second year after the auditor changes are all positive. The median changes are 
significant in the overall 2-year period and the first year after the auditor changes at the $10 \%$ and $5 \%$ level, respectively. Overall, the return and ROA analysis indicates that there is mild evidence that firms have positive stock return and earnings performance after the auditor changes. The audit fee savings provide net economic benefits to firms.

Table 3

Analysis of ROA Following Auditor Changes

\begin{tabular}{|c|c|c|c|}
\hline & \# of firms & Mean $^{\mathrm{a}}$ & Median $^{b}$ \\
\hline $\begin{array}{l}\text { Average annual change in ROA in two fiscal } \\
\text { years ending after auditor changes }\end{array}$ & 46 & $\begin{array}{c}0.01270 \\
(0.7387)\end{array}$ & $\begin{array}{c}0.02024 \\
(0.0725)\end{array}$ \\
\hline $\begin{array}{l}\text { Change in ROA in first fiscal year ending } \\
\text { after auditor changes }\end{array}$ & 46 & $\begin{array}{c}0.01172 \\
(0.7484)\end{array}$ & $\begin{array}{c}0.01804 \\
(0.0161)\end{array}$ \\
\hline $\begin{array}{l}\text { Change in ROA in second fiscal year ending } \\
\text { after auditor changes }\end{array}$ & 46 & $\begin{array}{c}0.00676 \\
(0.8678)\end{array}$ & $\begin{array}{r}0.01049 \\
(0.3713)\end{array}$ \\
\hline
\end{tabular}

ROA = Income before discontinued operations and extraordinary items / ((total assets of current year + total assets of last year) / 2)

Change in $\mathrm{ROA}=\mathrm{ROA}$ in the period after the auditor change minus the average ROA in the two fiscal years ended before the change in auditor.

ROA and change in ROA are winsorized to be within $+/-1$ to avoid outlier problems.

a: two-tailed $p$-value for $t$-test of sample mean in parenthesis.

b: two-tailed $p$-value for sign test of sample median in parenthesis.

We next examined if the return and ROA performance is affected by the type of auditor change. The results provided in Table 4 show that there is no significant difference in stock and ROA performance of firms among the four types of auditor changes. On possible reason for our results is that these firms changed auditors primarily to save audit fees without other regulatory and disclosure issues. Thus, different types of auditor change are not associated with different positive or negative signals.

Table 4

Analysis of Stock Returns and ROA Following Auditor Changes by Types of Auditor Changes

\begin{tabular}{|c|c|c|}
\hline \multicolumn{3}{|c|}{ Model: $\alpha_{i}$ or change in $\mathbf{R O A}_{i}=a_{0}+a_{1} B B_{i}+a_{2} B_{i}+a_{3} N_{i}+e_{i}$} \\
\hline & \multicolumn{2}{|c|}{ Dependent variable } \\
\hline & Intercept of 4-factor model ${ }^{\mathrm{a}}$ & Average annual change in $\mathbf{R O A}^{\mathrm{b}}$ \\
\hline \multirow[t]{2}{*}{ Intercept } & 0.00032 & -0.02028 \\
\hline & $(0.9367)^{\mathrm{c}}$ & $(0.9381)^{\mathrm{c}}$ \\
\hline \multirow[t]{2}{*}{$\mathrm{BB}$} & -0.00010 & 0.08130 \\
\hline & $(0.9798)$ & $(0.7693)$ \\
\hline \multirow[t]{2}{*}{$\mathrm{BN}$} & -0.00021 & 0.06163 \\
\hline & $(0.9576)$ & $(0.8171)$ \\
\hline \multirow[t]{2}{*}{$\mathrm{NN}$} & 0.00200 & -0.05616 \\
\hline & $(0.6321)$ & $(0.8364)$ \\
\hline Adjusted $\mathrm{R}^{2}$ & 0.0005 & -0.0224 \\
\hline \multirow[t]{2}{*}{ F-statistic } & 1.01 & 0.67 \\
\hline & $(0.3974)$ & $(0.5748)$ \\
\hline \# of observations & 51 & 46 \\
\hline \multicolumn{3}{|c|}{$\begin{array}{l}\mathrm{BB}=1 \text { if firm } \mathrm{i} \text { changed its auditor from a Big } 4 \text { public accounting firm to another Big } 4 \text { public accounting firm; } 0 \text { otherwise. } \\
\mathrm{BN}=1 \text { if firm } \mathrm{i} \text { changed its auditor from a Big } 4 \text { public accounting firm to a non-Big } 4 \text { public accounting firm; } 0 \text { otherwise. } \\
\mathrm{NN}=1 \text { if firm } \mathrm{i} \text { changed its auditor from a non-Big } 4 \text { public accounting firm to another non-Big } 4 \text { public accounting firm; } 0 \\
\text { otherwise. } \\
\mathrm{a}: \mathrm{R}_{\mathrm{it}}-\mathrm{R}_{\mathrm{ft}}=\alpha+\mathrm{b}\left(\mathrm{R}_{\mathrm{mt}}-\mathrm{R}_{\mathrm{ff}}\right)+\mathrm{sMB}_{\mathrm{t}}+\mathrm{hHML}_{\mathrm{t}}+\mathrm{uUMD}_{\mathrm{t}}+\varepsilon_{\mathrm{t}} \\
\mathrm{b}: \text { average annual change in ROA in the two fiscal years ending after the auditor change. } \\
\text { c: two-tailed } p \text {-value in parenthesis. }\end{array}$} \\
\hline
\end{tabular}


As discussed in the previous sections, the high compliance costs of Section 404 have caused many firms to change auditors to reduce audit fees (Ettredge et al. 2007). Thus, we compared the return and ROA performance between firms with auditor changes made before 2004 and firms with auditor changes made since 2004. Results of the analysis are reported in Panel A of Table 5. For the pre-2004 period, the results show that the median stock return for all firms is positive and significant at the 5\% level. In addition, ROA in the first fiscal year ending after the auditor change is positive and statistically significant at the $10 \%$ level. These results are consistent with the results of the overall sample. On the other hand, the stock and ROA performance of firms with auditor changes made in the period since 2004 are not statistically different from zero. Panel B reports the results in comparing the stock and ROA performance in these two periods using a regression approach. The coefficient estimates for Year 2004 are negative and significant in both regression models. The results indicate that the stock and ROA performance after the auditor changes is more positive in the pre-2004 period than in the later period.

Table 5

Average Stock Returns and Earnings Performance Following Auditor Changes in Periods Before and Since 2004 Panel A: Summary statistics of stock and earnings performance in the two periods

\begin{tabular}{|c|c|c|c|c|}
\hline & \multicolumn{2}{|c|}{ Before 2004} & \multicolumn{2}{|c|}{ Since 2004 or after } \\
\hline & Mean $^{\mathbf{a}}$ & Median $^{b}$ & Mean $^{\mathrm{a}}$ & Median $^{\mathrm{b}}$ \\
\hline Intercept of 4-factor model & $\begin{array}{r}0.00194 \\
(0.1249)\end{array}$ & $\begin{array}{r}0.00138 \\
(0.0169)\end{array}$ & $\begin{array}{l}-0.00017 \\
(0.5438)\end{array}$ & $\begin{array}{r}0.00015 \\
(0.4583)\end{array}$ \\
\hline $\begin{array}{l}\text { Average annual change in ROA in two fiscal } \\
\text { years ending after auditor changes }\end{array}$ & $\begin{array}{r}0.08996 \\
(0.2438)\end{array}$ & $\begin{array}{r}0.02131 \\
(0.3593)\end{array}$ & $\begin{array}{l}-0.04165 \\
(0.2469)\end{array}$ & $\begin{array}{r}0.01917 \\
(0.1686) \\
\end{array}$ \\
\hline $\begin{array}{l}\text { Change in ROA in first fiscal year ending } \\
\text { after auditor changes }\end{array}$ & $\begin{array}{r}0.10054 \\
(0.1545)\end{array}$ & $\begin{array}{r}0.04009 \\
(0.0636)\end{array}$ & $\begin{array}{l}-0.05078 \\
(0.1686)\end{array}$ & $\begin{array}{r}0.01560 \\
(0.1686)\end{array}$ \\
\hline $\begin{array}{l}\text { Change in ROA in second fiscal year ending } \\
\text { after auditor changes }\end{array}$ & $\begin{array}{r}0.06260 \\
(0.4338)\end{array}$ & $\begin{array}{r}0.02523 \\
(0.6476)\end{array}$ & $\begin{array}{l}-0.03252 \\
(0.4364)\end{array}$ & $\begin{array}{r}0.00870 \\
(0.5572)\end{array}$ \\
\hline \multicolumn{5}{|c|}{ Panel B: Regression analysis of the differences in stock and earnings performance in the two periods } \\
\hline \multicolumn{5}{|c|}{ Dependent variable } \\
\hline Intercept & \multicolumn{4}{|c|}{$\begin{array}{l}0.08996 \\
(0.1255)\end{array}$} \\
\hline Year2004 & \multicolumn{4}{|c|}{$\begin{array}{l}-0.13162 \\
(0.0870)\end{array}$} \\
\hline Adjusted $\mathrm{R}^{2}$ & \multicolumn{4}{|c|}{0.0439} \\
\hline F-statistic & \multicolumn{4}{|c|}{$\begin{array}{l}3.06 \\
(0.0870)\end{array}$} \\
\hline \# of observations & \multicolumn{4}{|c|}{46} \\
\hline
\end{tabular}

Year2004 = 1 for auditor changes made since 2004; 0 otherwise.

a: two-tailed $p$-value for $t$-test of sample mean in parenthesis.

b: two-tailed $p$-value for sign test of sample median in parenthesis.

c: $\mathrm{R}_{\mathrm{it}}-\mathrm{R}_{\mathrm{ft}}=\alpha+\mathrm{b}\left(\mathrm{R}_{\mathrm{mt}}-\mathrm{R}_{\mathrm{ft}}\right)+\mathrm{sSMB}_{\mathrm{t}}+\mathrm{hHML} \mathrm{L}_{\mathrm{t}}+\mathrm{uUMD} \mathrm{D}_{\mathrm{t}}+\varepsilon_{\mathrm{t}}$

$\mathrm{d}$ : average annual change in ROA in the two fiscal years ending after the auditor change.

e: two-tailed $p$-value in parenthesis.

\section{CONCLUDING REMARKS}

This study examined the stock return and earnings performance after firms changed auditors for audit fee savings. The findings suggest mild evidence that the stock return and earnings performance is positive after the auditor changes. This implies that there is a positive result when firms change auditors to save audit fees. Furthermore, analysis showed that the overall positive performance is common to all types of auditor changes changing among or between Big 4 and non-Big 4 auditors. Finally, the mild positive stock and earnings performance subsequent to auditor changes occur mainly in the period before 2004. Auditor changes since 2004 have a neutral stock and earnings performance that is not significantly different from zero. This may reflect the substantial increase in auditor services related to Section 404 compliance and the increasing importance of the monitoring role of 
auditors in the recent years that demand better corporate governance and disclosure transparency. Accordingly, the trade-off between potential cost saving and the opportunity cost of having small non-Big 4 auditors or lesscompensated auditors is different and not as positive since 2004 .

\section{AUTHOR INFORMATION}

Kam C. Chan is a professor of accounting at the Lubin School of Business at Pace University. He received his $\mathrm{Ph} . D$. degree from the University of South Carolina in 1991. His research interests include capital market research in auditing, financial accounting, and international accounting. He has published in top journals such as Accounting, Organizations and Society, Auditing: A Journal of Practice and Theory, Journal of Accounting and Economics, Journal of Business Finance and Accounting, Journal of International Accounting Research, and Journal of Multinational Financial Management. E-mail: kchan@ pace.edu

Barbara Farrell is a professor at Pace University. Dr. Farrell has extensive experience teaching in corporate classes. These classes included CMA review and computer application classes for corporations such as IBM, Readers Digest and many others. Dr. Farrell has a BBA and MBA from Pace University and an EdD from Columbia University. She is a CPA. Prior to entering education, Dr. Farrell was an auditor in both "Big 8" public accounting and in the private sector specializing in computer auditing. Dr. Farrell has published in CPA Journal, Journal of Forensic Accounting, and Auditing: A Journal of Practice and Theory. E-mail: bfarrell@ pace.edu

Patricia Healy is an associate professor of accounting and the undergraduate program chair for the accounting department at the Pace University. Professor Healy has received the Pace University Kenan Award for teaching excellence and the teacher of the year award from the Robert S. Pace accounting society. She was an auditor for PriceWaterhouseCoopers and is a CPA and a CMA. She has consulted for clients such as IBM, Corning, Kraft, and Hudson Valley Hospital Center. Professor Healy has published papers on international auditing standards, quality controls, diversity issues in business, implementing the Balanced Scorecard and governmental accounting issues. E-mail: phealy@pace.edu

Picheng Lee is a professor of accounting at Pace University. He is also a certified management accountant (CMA) and a member of editorial board of the International Journal of Accounting and Information Management. Dr. Lee obtained his Ph. D. degree from Rutgers University in 2000 and joined Pace University since then. Dr. Lee's research interest is in financial accounting and auditing. His papers has been published in various journals including Auditing: A Journal of Practice and Theory, Journal of Accounting, Auditing, and Finance, Journal of International Accounting Research, Journal of Forensic Accounting, and Review of Quantitative Finance and Accounting. E-mail: plee@pace.edu

\section{REFERENCES}

1. Bar-Yosel, S. and Livnat, J., 1984, Auditor selection: an incentive-signaling approach, Accounting and Business Research, Autumn: 301-309.

2. $\quad$ Becker, C., DeFond, M., Jiambalvo, J., and K. R. Subramanyam, K., 1998, The effect of audit quality on earnings management, Contemporary Accounting Research, Vol. 15, Spring: 1-24.

3. Benoit, B. 2006. The impact of Sarbanes-Oxley on the real estate industry. Banker \& Tradesman, February 27, available at www.insidesarbanesoxley.com/sarbanes-oxley-resources/lord-benoit/.

4. Cahan, S., Godfrey, J., Hamilton, J., and Jeter, D., 2008, Auditor specialization, auditor dominance, and audit fees: the role of investment opportunities, The Accounting Review, Vol. 83: 1393-1423.

5. Chang, X., Dasgupta, S., and Hilary, G., 2009, The effect of auditor quality on financing decisions, The Accounting Review, Vol. 84: 1085-1117.

6. $\quad$ Carhart, M., 1997, On Persistence in Mutual Fund Performance, Journal of Finance 52, 57-82.

7. Eldridge, S. and Kealey, B. 2005. SOA Attestation: What are the initial costs for banks? Bank Accounting \& Finance, Vol. 19, Issue 1: 3-12.

8. Ettredge, M., Li, C., and Scholz, S., 2007, Audit fees and auditor dismissals in the Sarbanes-Oxley era, Accounting Horizons, Vol. 21: 371-386. 
9. Fama, E. F. and French, K.R., 1993, Common risk factors in the returns on stocks and bonds, Journal of Financial Economics 33, 3-56.

10. Francis, J. Maydew, E., and Sparks, H., 1999, The role of Big 6 auditors in the credible reporting of accruals, Auditing: A Journal of Practice \& Theory, Vol. 18: 17-34.

11. Grothe, M. and Weirich, T., 2007, Analyzing auditor changes, The CPA Journal, December, Vol. 77: 1423.

12. Hackenbrack, K. and Hogan, C, 2002, Market response to earnings surprises conditional on reasons for an auditor change, Contemporary Accounting Research, Vol. 19: 195-223.

13. Hogan, C. and Martin, R., 2009, Risk shift in the market for audits: an examination of changes in risk for "second tier" audit firms, Auditing: A Journal of Practice \& Theory, Vol. 28: 93-118.

14. Jensen, M., and Meckling, W., 1976, Theory of the firm: managerial behavior, agency costs and ownership structure." Journal of Financial Economics, Vol. 3: 305-60.

15. Johnson, W., and Lys, T., 1990, The market for audit services: evidence from voluntary auditor changes, Journal of Accounting and Economics 12, 281-308.

16. Krishnan, J., 1994, Auditor switching and conservatism, The Accounting Review, Vol. 69: 200-215.

17. Mansi, S., Maxwell, W., and Miller, D., 2004, Does auditor quality and tenure matter to investor? Evidence from the bond market, Journal of Accounting Research, Vol. 42: 755-793.

18. Owens-Jackson, L., Robinson, D., and Shelton, S., 2008, Auditor resignations and dismissals, The CPA Journal, January, Vol. 78: 28-31.

19. Raghunandan, K. and Rama, D. 2006. SOX Section 404 material weakness disclosures and audit fees. Auditing: A Journal of Practice \& Theory 25, Vol. 25: 99-114.

20. Teoh, S. H. and Wong, T. J., 1993, Perceived auditor quality and the earnings response coefficient, The Accounting Review, Vol. 68: 346-366.

21. Turner, L., Williams, J., and Weirich, T., 2005, An inside look at auditor changes, The CPA Journal, November: 12-21.

22. Venkataraman, R., Weber, J., and Willenborg, M., 2008, Litigation risk, audit quality, and audit fees: evidence from initial public offerings, The Accounting Review, Vol. 83: 1315-1345. 


\section{NOTES}

